Available online: https://journal.uny.ac.id/index.php/jpa

Jurnal Pendidikan Anak, Volume 9 (2), 2020, 140-149

\title{
Peningkatan kemampuan motorik halus melalui permainan melipat pada anak kelompok A di TK Negeri Pembina Bantul
}

\author{
Siti Akhiyati \\ TK Negeri Pembina Bantul Yogyakarta \\ Jl. Parangtritis Km 8.5 Tembi Timbulharjo Sewon Bantul Yogyakarta Indonesia \\ E-mail: Sitiakhiyatirizal@yahoo.co.id
}

\begin{tabular}{|c|c|}
\hline ARTICLE INFO & ABSTRACT \\
\hline \multirow[t]{2}{*}{$\begin{array}{l}\text { Article history: } \\
\text { Received:24-04-2020 } \\
\text { Revised: 05-05-2020 } \\
\text { Accepted: } 18-05-2020 \\
\text { Keywords: } \\
\text { kemampuan motorik halus, } \\
\text { melipat, anak }\end{array}$} & $\begin{array}{l}\text { Kemampuan motorik halus menjadi salah satu dasar bagi kemampuan menulis anak. } \\
\text { Penelitian ini bertujuan untuk meningkatkan kemampuan motorik halus melalui } \\
\text { permainan melipat pada kelompok A di TK Pembina Negeri Bantul. Penelitian ini } \\
\text { merupakan penelitian tindakan kelas yang menggunakan metode Kemmis dan Mc } \\
\text { Taggart, yang meliputi tahap perencanaan, tindakan, observasi dan refleksi. Subjek } \\
\text { penelitian adalah } 20 \text { anak yang terdiri dari } 12 \text { anak laki-laki dan } 8 \text { anak perempuan. } \\
\text { Metode pengumpulan data menggunakan observasi. Instrumen pengumpulan data } \\
\text { berupa lembar observasi. Kriteria keberhasilan dalam penelitian ini adalah } 80 \% \text {. } \\
\text { Adapun teknik analisis data menggunakan analisis data kuantitatif dan kualitatif. } \\
\text { Hasil penelitian menunjukkan bahwa kemampuan motorik halus anak dapat } \\
\text { ditingkatkan melalui kegiatan melipat. Hal ini dapat dilihat dari kemampuan } \\
\text { motorik halus anak yang mencapai mencapai BSH (Berkembang Sesuai Harapan) } \\
\text { mengalami peningkatan yang semula } 3 \text { anak (17 \%) pada Siklus I menjadi } 5 \text { anak } \\
\text { (27,8 \%) pada Siklus II, artinya peningkatannya sebesar } 13,8 \% \text {. Selain itu, } \\
\text { kemampuan motorik halus anak yang mencapai BSB (Berkembang Sangat Baik) } \\
\text { mengalami peningkatan yang semula ada } 5 \text { anak (28 \%) yang mencapai BSB pada } \\
\text { Siklus I, menjadi } 11 \text { anak (61,1 \%) pada Siklus II, artinya peningkatannya sebesar } \\
33,1 \% \text {. }\end{array}$ \\
\hline & $\begin{array}{l}\text { Fine motor skills become one of the foundations for children's writing abilities. This } \\
\text { research aims to improve fine motor skills through folding activities in group A in } \\
\text { TK Pembina Negeri Bantul. This research is a classroom action research using the } \\
\text { Kemmis and Mc Taggart methods, which includes the stages of planning, action, } \\
\text { observation and reflection. Subjects were } 20 \text { children consisting of } 12 \text { boys and } 8 \\
\text { girls. The data collection method uses observation. Data collection instruments in } \\
\text { the form of observation sheets. The criterian of success in this study is } 80 \% \text {. The data } \\
\text { analysis technique uses quantitative and qualitative data analysis. The results } \\
\text { showed that children's fine motor skills can be improved through folding activities. } \\
\text { This can be seen from the fine motor skills of children who reach BSH (Developing } \\
\text { in line with Expectations) which increased from } 3 \text { children (17\%) in Cycle I to } 5 \\
\text { children (27.8\%) in Cycle II, meaning an increase of } 13.8 \% \text {. In addition, the fine } \\
\text { motoric abilities of children who reach BSB (Very Good Development in Cycle I) } \\
\text { experienced an increase from } 5 \text { children (28\%) who reached BSB, to } 11 \text { children } \\
\text { (61.1\%) in Cycle II, meaning an increase of 33.1\%. }\end{array}$ \\
\hline
\end{tabular}


Jurnal Pendidikan Anak, Volume 9 (2) Tahun 2020

Siti Akhiyati

\section{PENDAHULUAN}

Taman Kanak-kanak merupakan bagian dari pendidikan prasekolah yang keberadaannya sudah tidak asing lagi. Pendidikan anak usia dini menurut Undang-undang Sisdiknas Nomor 20 Tahun 2003 pasal 1 ayat 14 adalah suatu upaya yang ditujukan kepada anak sejak lahir sampai dengan usia 6 tahun yang dilakukan melalui pemberian rangsangan pendidikan yang membantu pertumbuhan dan perkembangan jasmani dan rohani agar anak memiliki kesiapan dalam memasuki pendidikan lebih lanjut.

Masa kanak-kanak dengan usia 4-6 tahun merupakan masa bermain sehingga kegiatan pendidikan di Taman Kanak-kanak perlu diberikan melalui metode bermain. Kegiatan belajar mengajar dikemas dalam kegiatan belajar sambil bermain dan bermain sambil belajar, yaitu dengan permainan yang kreatif dan menyenangkan. Di lembaga PAUD, terdapat enam aspek perkembangan yang distimulasi, yaitu nilai agama dan moral, fisik motorik, kognitif, bahasa, sosial emosional, dan seni. Keenam aspek perkembangan tersebut perlu distimulasi secara menyeluruh.

Perkembangan motorik merupakan salah satu perkembangan yang penting distimulasi sejak dini. Kemampuan fisik motorik anak usia dini terdiri dari motorik kasar dan motorik halus. Motorik kasar adalah kemampuan gerak dimana pada saat bergerak menggunakan otot-otot besar. Sedangkan motorik halus adalah kemampuan gerak yang melibatkan otot-otot kecil. Pada anak usia Taman Kanak-kanak, guru perlu meningkatkan keterampilan tubuh dan koordinasi, serta meningkatkan keterampilan tubuh dan cara hidup sehat, sehingga dapat mendukung pertumbuhan jasmani yang kuat, sehat, dan terampil.

Kemampuan motorik halus menjadi salah satu kemampuan yang perlu distimulasi karena menjadi dasar bagi kemampuan menulis anak. Menurut Sujiono, dkk (2010: p 1.14), kemampuan motorik halus anak adalah gerakan yang hanya melibatkan bagian-bagian tubuh tertentu saja dan dilakukan oleh otot-otot kecil, seperti menggunakan jari jemari, tangan, dan gerakan pergelangan tangan yang tepat, gerakan ini tidak membutuhkan tenaga namun membutuhkan koordinasi mata dan tangan dengan baik. Semakin baiknya gerakan motorik halus anak, dapat mendorong anak mampu berkreasi, seperti menggunting kertas, menggambar, menjahit, menganyam, melipat, dan menajamkan pensil dengan rautan. Lebih lanjut, Yamin dan Sanan (2013: p 101-103) menjelaskan kemampuan motorik halus anak meliputi: menggenggam, memegang, merobek, menggunting, dan koordinasi mata serta tangan.

Peraturan Menteri Pendidikan dan Kebudayaan Republik Indonesia No 137 Tahun 2014, menyebutkan bahwa indikator perkembangan motorik halus anak usia 4-5 tahun meliputi: 1) membuat garis vertikal, horisontal, lengkung kiri/kanan, miring kiri/kanan dan lingkaran; 2) menjiplak bentuk; 3) mengkoordinasikan mata dan tangan untuk melakukan gerakan yang rumit; 4) melakukan gerakan manipulatif untuk menghasilkan suatu bentuk dengan menggunakan media; 5) mengekspresikan diri dengan berkarya seni menggunakan berbagai media; dan 6) mengontrol gerakan tangan yang menggunakan otot halus (menjumput, mengelus, mencolek, mengepal, memelintir, memilin, meremas).

Berdasarkan pengamatan yang dilakukan pada anak kelompok A1 yang berjumlah 20 anak menunjukkan bahwa kemampuan motorik halus anak masih rendah. Hal ini tampak pada baru 14 anak belum mampu menggunting dengan terampil dan rapi, 12 anak belum mampu mencocok dengan terampil, 16 anak belum mampu finger painting dengan lentur dan masih belepotan, 15 anak belum mampu membentuk dengan plastisin sesuai tema, serta 17 anak yang mampu merobek kertas sesuai garis. Sejauh ini guru telah berupaya untuk meningkatkan kemampuan motorik halus anak melalui berbagai kegiatan seperti menggunting, mencocok, finger painting dan lainnya, namun kemampuan motorik halus anak belum optimal. 
Jurnal Pendidikan Anak, Volume 9 (2) Tahun 2020

Siti Akhiyati

Upaya yang dapat dilakukan oleh guru dalam meningkatkan kemampuan motorik anak dapat dilakukan melalui media yang kreatif dan menyenangkan bagi anak. Guru dapat menggunakan berbagai media yang menarik bagi anak, dan dapat melaksanakan kegiatan yang dapat melatih otototot tangan dan melatih koordinasi mata, tangan dan pikiran anak. Untuk mengatasi permasalahan terkait kemampuan motorik halus yang masih rendah, maka peneliti menggunakan kegiatan melipat. Menurut Sumantri (2005), melipat merupakan seni yang cocok bagi anak untuk melatih keterampilan tangan anak, kerapian dalam berkreasi, disajikan dengan minat anak yang akan memberikan keasikan dan kegembiraan serta kepuasan bagi anak. Berdasarkan hasil pengamatan tersebut maka peneliti berinisiatif untuk meningkatkan kemampuan motorik halus melalui kegiatan melipat.

\section{METODE}

Penelitian ini menggunakan desain penelitian model Kemmis dan Mc Taggart dimana setiap siklusnya mengikuti langkah-langkah sistematis sesuai dengan kaidah-kaidah penelitian. Tahapantahapan penelitian dalam model Kemmis dan Mc Taggart meliputi: (1) perencanaan (planning), (2) tindakan (action), (3) pengamatan (observation), dan (4) refleksi (reflection) (Sa'dun, 2009: p 30). Empat tahap tersebut dapat digambarkan pada Gambar 1 di bawah ini.

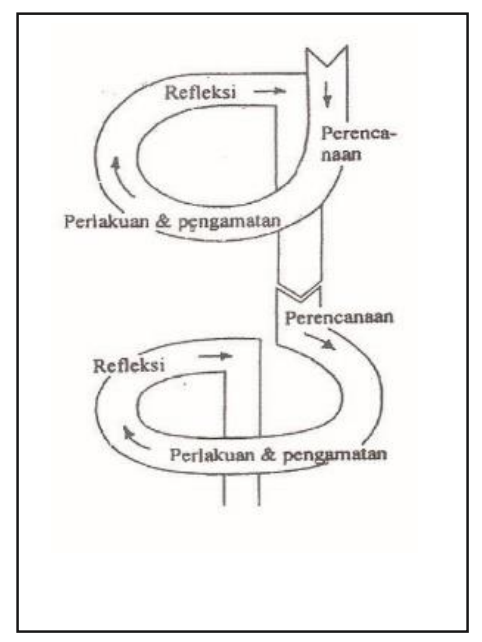

Gambar 1. Siklus Penelitian Tindakan Kelas dari Kemmis \& Mc. Taggart

Metode pengumpulan data yang dipakai dalam penelitian ini menggunakan observasi. Melalui metode observasi, peneliti mengamati langsung kemampuan motorik halus anak melalui kegiatan melipat. Hasil kegiatan dicatat dalam lembar observasi dengan memberi tanda checklist (v). Penelitian ini menggunakan instrumen penelitian berupa lembar observasi. Adapun kriteria keberhasilan dalam tindakan dalam penelitian ini ditentukan berdasarkan kesepakatan antara peneliti dan kolaborator yaitu sebesar $80 \%$. Adapun teknik analisis data dilakukan secara deskriptif kuantitif dan kualitatif. Analisis deskriptif kuantitatif digunakan untuk mengolah dan menganalisis data angka yang terkumpul dari peningkatan kemampuan motorik halus melalui kegiatan melipat. Hasil akhir dari observasi dapat digunakan untuk mengetahui persentase kemampuan motorik halus anak, serta hasil yang diperoleh dalam perhitungan kuantitatif kemudian diinterprestasikan dalam kalimat. Sudjiono (Jakni, 2017: p 82) memaparkan rumus sebagai berikut. 
Jurnal Pendidikan Anak, Volume 9 (2) Tahun 2020

Siti Akhiyati

$$
\mathrm{P}=\frac{f}{N} X 100 \%
$$

Keterangan:

$\mathrm{P}$ : Angka persentase

$\mathrm{N}$ : Jumlah frekuensi atau banyaknya individu (number of case)

$\mathrm{F}$ : Frekuensi yang sedang dicari presentasenya

Perolehan data berasal dari lembar observasi yang diisi pada saat kegiatan pembelajaran berlangsung. Berdasarkan data hasil obervasi yang diperoleh, maka selanjutnya data dihitung kemudian dipersentasekan. Jika sudah memperoleh data persentase, maka hasil perhitungan akan dikelompokkan ke dalam kategori-kategori. Jakni (2017: p 82) membagi kategori tersebut sebagai berikut.

Tabel 1. Tolak ukur kategori persentase

\begin{tabular}{cc}
\hline Persentase & Kategori \\
\hline $75,01-100,00$ & Sangat Baik \\
\hline $50,01-75,00$ & Baik \\
\hline $25,01-50,00$ & Cukup \\
\hline $00,00-25,00$ & Kurang
\end{tabular}

Selanjutnya analisis data kualitatif dilakukan dengan cara memberikan narasi secara runtut pada tiap tahapan atau prosedur penelitian.

\section{HASIL DAN PEMBAHASAN}

\section{Hasil \\ Pratindakan}

Berdasarkan hasil pengamatan saat Pratindakan, diperoleh data awal kemampuan motorik halus anak yang berkembang sangat baik dan berkembang sesuai harapan hanya ada 3 anak (15\%) saja, sedangkan 17 anak lainnya belum berkembang yaitu mencapai $85 \%$ anak yang masih memerlukan bantuan/bimbingan dalam menyelesaikan kegiatan motorik halus. Selain itu, sebagian anak juga masih kaku atau belum lentur tangannya, hasil lipatan masih lusuh dan belum rapi, saat menempel dengan lem masih belepotan dan ada yang terbalik, dari 14 anak belum mampu menggunting dengan terampil dan rapi, 12 anak belum mampu mencocok dengan terampil, 16 anak belum mampu finger painting dengan lentur dan masih belepotan, 15 anak belum mampu membentuk dengan plastisin sesuai tema, serta 17 anak yang mampu merobek kertas sesuai garis.

\section{Siklus I}

\section{Perencanaan}

Guru menyiapkan Rencana Pelaksanaan Pembelajaran Harian/RPPH, menyiapkan alat/media yang digunakan dalam proses pembelajaran yaitu berupa lembar observasi untuk pegangan kolaborator dalam mencatat perkembangan anak. 
Jurnal Pendidikan Anak, Volume 9 (2) Tahun 2020

Siti Akhiyati

\section{Pelaksanaan /Tindakan}

Siklus I pertemuan pertama dilaksanakan pada hari Kamis tanggal 21 Februari 2019 untuk kemampuan melipat bentuk gunung dengan kertas lipat tipis satu warna. Sebelum kegiatan inti dilaksanakan guru menjelaskan dan memberi contoh tentang cara melipat bentuk gunung.

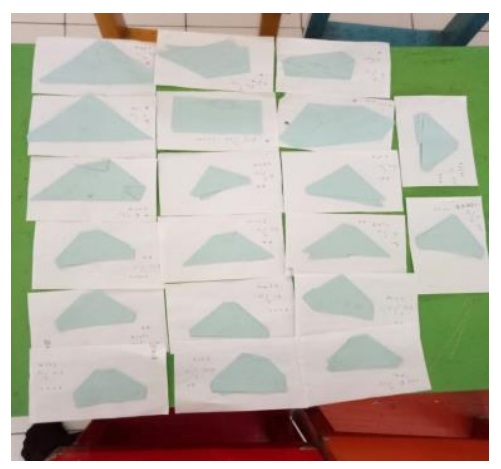

Gambar 2. Hasil melipat bentuk gunung

Siklus I pertemuan kedua dilaksanakan pada hari Selasa tanggal 26 Februari 2019 dengan kegiatan melipat bentuk pohon dengan menggunakan kertas lipat warna hijau. Sebelum kegiatan inti dilaksanakan guru menjelaskan dan memberi contoh tentang cara melipat bentuk pohon, yaitu "kertas dilipat menjadi bentuk segitiga, 2 garis ditepi ditarik ke garis tengah, ulangi untuk ujung yang satunya, salah satu ujung di lipat keatas dan dilipat sebagian ke bawah hingga membentuk batangnya".

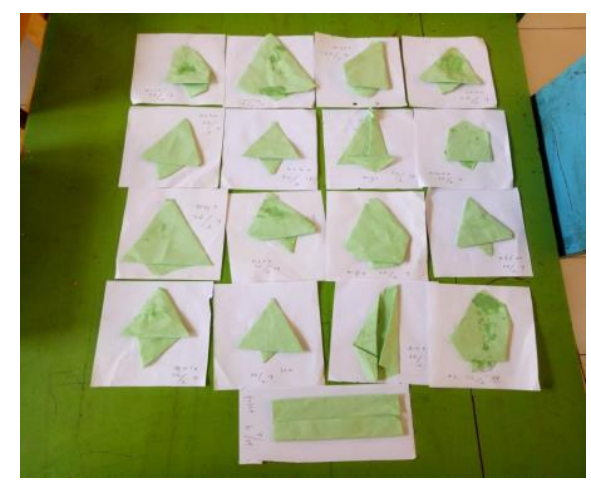

Gambar 3. Hasil melipat bentuk pohon

\section{Observasi/Pengamatan}

Berdasarkan hasil pengamatan yang dilakukan Siklus I tampak sebagian anak antusias dalam mengikuti pembelajaran dari memilih tempat, mengambil kertas, dan mulai melipat tahap demi tahap dengan telaten tanpa ada pertanyaan pada guru. Namun ada juga sebagian anak yang kurang memperhatikan penjelasan guru karena asyik bercerita dengan teman, tiduran di karpet, ada yang masih dibantu guru ataupun teman lain dalam melipat. Adapun hasil pengamatan kemampuan motorik halus anak melalui kegiatan melipat adalah sebagai berikut. 
Jurnal Pendidikan Anak, Volume 9 (2) Tahun 2020

Siti Akhiyati

Tabel 1. Penilaian kemampuan melipat Siklus I

\begin{tabular}{cccc}
\hline & & Kriteria & \multicolumn{2}{c}{ Hasil Pengamatan } \\
\cline { 3 - 4 } No & & Jumlah Anak & Persentase \\
\hline 1 & BSB & 5 & $28 \%$ \\
\hline 2 & BSH & 3 & $17 \%$ \\
& & & \\
\hline 3 & MB & 6 & $33 \%$ \\
& & & \\
4 & BB & 4 & $22 \%$ \\
\hline
\end{tabular}

Berdasarkan Tabel 1 dapat dilihat perhitungan hasil pengamatan kemampuan melipat bentuk gunung, jumlah anak yang mencapai kriteria BSB dan BSH baru mencapai 8 anak (45\%), sedangkan anak yang berada pada kriteria MB dan BB ada 10 anak (55\%).

\section{Refleksi}

Tabel 1 menunjukkan bahwa hasil belajar anak belum mencapai indikator keberhasilan $80 \%$, karena dari 18 anak, baru 3 anak yang berada pada kriteria BSH dan 5 anak yang berada pada kriteria BSB. Oleh karena itu perlu diadakan tindakan lanjutan pada Siklus II.

Hasil evaluasi dan hasil diskusi antara guru dan kolaborator menunjukkan beberapa hal yang dapat direfleksikan ke dalam tindakan selanjutnya, agar pelaksanaan proses pembelajaran kemampuan melipat anak di kelompok A1 TK Negeri Pembina Bantul dapat lebih meningkat lagi kualitas pembelajarannya. Hasil refleksi tersebut yaitu: masih ada anak yang bermain sendiri, tiduran di karpet dan asyik bercerita/bercakap-cakap dengan teman, masih ada juga anak yang kurang percaya diri, dan sering memanggil-manggil guru untuk membantunya dalam melipat.

Pada Siklus II diharapkan bisa ditindak lanjuti dengan cara memotivasi anak melalui cerita dan pemberian reward, melatih anak dengan berulang-ulang, dan dengan menggunakan media yang lebih menarik lagi, agar anak lebih semangat dalam pembelajaran. Dengan demikian kemampuan motorik halus anak menunjukkan perubahan signifikan, yaitu dari Belum Berkembang (BB) menjadi Berkembang Sesuai Harapan (BSH) atau Berkembang Sangat Baik (BSB) sesuai dengan kriteria atau target yang telah ditentukan yaitu $80 \%$.

Tabel 2. Simpulan Siklus 1 dan Tindak Lanjut Siklus 2

\begin{tabular}{ll}
\hline \multicolumn{1}{c}{ Simpulan Siklus 1 } & \multicolumn{1}{c}{ Tindak Lanjut Siklus 2 } \\
\hline Anak masih dibantu & Memotivasi anak dengan cerita \\
\hline Anak tiduran di karpet & Ada kesepakatan dan reward \\
\hline Jari jemari belum lentur & Latihan berulang ulang \\
\hline Anak asyik bercerita sendiri & Dengan media yang lebih menarik \\
\hline Kertas tipis satu warna & Kertas lipat origami warna-warni \\
\hline
\end{tabular}

Copyright $@$ ( 2020, Jurnal Pendidikan Anak ISSN 2302-6804 (print), ISSN 2579-4531 (online) 
Jurnal Pendidikan Anak, Volume 9 (2) Tahun 2020

Siti Akhiyati

\section{Siklus II \\ Perencanaan}

Perencanaan tindakan disusun meliputi perencanaan pembelajaran berupa Rencana Pelaksanaan Pembelajaran Harian (RPPH), persiapan bahan dan alat untuk kegiatan melipat dan membuat lembar penilaian observasi kegiatan pembelajaran melipat anak.

\section{Pelaksanaan/Tindakan}

Siklus II pertemuan pertama dilaksanakan pada hari Sabtu tanggal 9 Maret 2019 di sudut sensorik menggunakan kertas origami warna warni melipat bentuk baju dengan kertas lipat origami berbagai warna. Adapun tema pada Siklus II yaitu Negara dengan sub tema Tanah airku (kota).

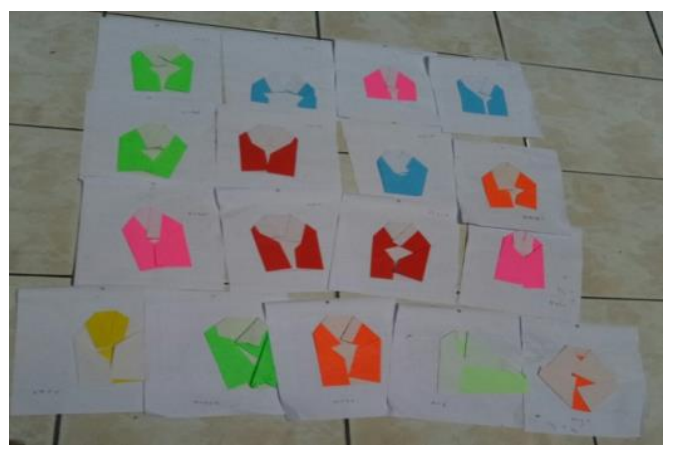

Gambar 4. Hasil melipat bentuk baju

Siklus II pertemuan kedua dilaksanakan pada hari Senin tanggal 1 Maret 2019 di sudut latihan kehidupan praktis menggunakan kertas origami warna warni melipat bentuk botol. Anak-anak mengerjakan tugas di sudut yang dibuka sesuai dengan pilihannya. Kertas yang disediakan warna-warni dan menarik, sehingga anak terlihat bersemangat dan senang dalam melipat. Guru menjelaskan dan memberi contoh tentang cara melipat bentuk botol "kertas dilipat menjadi bentuk persegi panjang dua kali, buka kertas lipat untuk kemudian tiap ujung dilipat ke dalam hingga terbentuk segiempat, lipat 1 ujung ke belakang, lipat 2 sisi ke arah bawah, buka ujung sampai terbuka, lipat 3 sisi yang lain sedikit sampai terlihat bentuk botol".

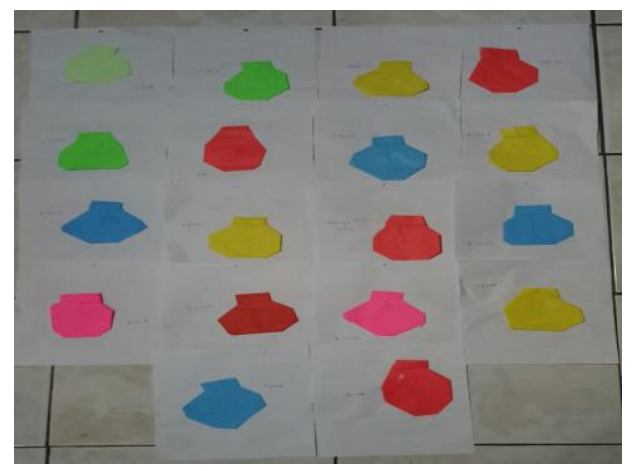

Gambar 5. Hasil melipat bentuk botol 
Jurnal Pendidikan Anak, Volume 9 (2) Tahun 2020

Siti Akhiyati

\section{Observasi/Pengamatan}

Hasil pengamatan yang dilakukan dalam pembelajaran menunjukkan bahwa kemampuan motorik halus anak dalam melipat pada Siklus II yaitu, anak-anak antusias dalam mengikuti pembelajaran dari memilih tempat, mengambil kertas, dan mulai melipat bentuk botol tahap demi tahap dengan telaten, melakukan sendiri sesuai dengan penjelasan guru, sudah tidak ada anak yang tiduran di karpet dan bercerita sendiri, sebagian besar anak tampak bersemangat dan telaten dalam melipat karena sebelum mulai kegiatan ada motivasi dari guru melalui cerita dan pemberian reward, serta pemakaian kertas yang digunakan berbeda dengan yang digunakan pada Siklus I, yaitu kertas lipat origami warna-warni yang tampak lebih menarik.

Tabel 3. Kemampuan Melipat Siklus 2

\begin{tabular}{|c|c|c|c|}
\hline \multirow[b]{2}{*}{ No } & \multirow[t]{2}{*}{ Kriteria } & \multicolumn{2}{|c|}{ Hasil Pengamatan } \\
\hline & & Jumlah Anak & Persentase \\
\hline 1 & BSB & 11 & $61,1 \%$ \\
\hline 2 & BSH & 5 & $27,8 \%$ \\
\hline 3 & MB & 2 & $11,1 \%$ \\
\hline 4 & $\mathrm{BB}$ & 0 & $0 \%$ \\
\hline & Jumlah & 18 & $100 \%$ \\
\hline
\end{tabular}

Berdasarkan Tabel 3 dapat dilihat perhitungan hasil pengamatan kemampuan melipat bentuk botol susu anak yang berada pada kriteria BSB dan BSH sudah mencapai 88,9\%, sedangkan anak yang mencapai MB hanya ada 2 anak saja sekitar 11,1\%. Dengan demikian dari data tersebut dapat disimpulkan bahwa hasil belajar anak sudah mencapai indikator/target keberhasilan $80 \%$. Dari 18 anak sudah terdapat 16 anak yang berada pada kriteria BSH dan BSB, sehingga tindakan dihentikan.

Tabel 4. Persentase Peningkatan Kemampuan Melipat

\begin{tabular}{lccc}
\hline $\begin{array}{l}\text { Kemampuan Melipat } \\
\text { Anak }\end{array}$ & Siklus 1 & Siklus 2 & $\begin{array}{c}\text { Peningkatan } \\
\text { Kemampuan } \\
\text { Melipat }\end{array}$ \\
\hline Belum Berkembang & $22 \%$ & $0 \%$ & $-22 \%$ \\
\hline $\begin{array}{l}\text { Mulai Berkembang } \\
\text { Berkembang Sesuai }\end{array}$ & $33 \%$ & $11,1 \%$ & $-21,9 \%$ \\
$\begin{array}{l}\text { Harapan } \\
\text { Berkembang Sangat } \\
\text { Baik }\end{array}$ & $28 \%$ & $27,8 \%$ & $13,8 \%$ \\
\hline
\end{tabular}

Copyright (C) 2020, Jurnal Pendidikan Anak ISSN 2302-6804 (print), ISSN 2579-4531 (online) 
Jurnal Pendidikan Anak, Volume 9 (2) Tahun 2020

Siti Akhiyati

Berdasarkan Tabel 4 dapat dilihat bahwa kemampuan motorik halus anak kel A1 TK Negeri Pembina Bantul melalui kegiatan melipat dari Siklus I dan Siklus II ada peningkatan yang signifikan yaitu pada Berkembang Sangat Baik (BSB) meningkat 33,1\%, dan Berkembang Sesuai Harapan (BSH) meningkat 13,8 \%. Sedangkan Belum Berkembang (MB) berkurang 21,9\%, dan Mulai Berkembang Berkurang (BB) menurun $22 \%$.

\section{Pembahasan}

Hasil penelitian tindakan yang dilakukan menunjukkan bahwa kemampuan motorik halus dapat ditingkatkan melalui kegiatan melipat. Kemampuan motorik halus perlu distimulasi pada anak usia 4-5 tahun. Pernyataan ini sesuai dengan pendapat Susilowati (2008) yang menyatakan bahwa, tahap perkembangan motorik halus anak usia 4-5 tahun meliputi: melipat, membangun menara setinggi 11 kotak, menggambar sesuatu yang berarti bagi anak tersebut dan dapat dikenali oleh orang lain, mempergunakan gerakan jemari selama permainan jari, menjiplak gambar kotak, dan menulis beberapa huruf. Hal tersebut diperkuat Peraturan Menteri Pendidikan dan Kebudayaan Republik Indonesia No137 tahun 2014 bahwa indikator perkembangan motorik halus anak usia 4-5 tahun adalah sebagai berikut: membuat garis vertikal, horizontal, lengkung kiri/kanan, miring kiri/kanan dan lingkaran, menjiplak bentuk, mengkoordinasikan mata dana tangan untuk melakukan gerakan yang rumit, m,elakukan gerakan manipulatif untuk mengahasilkan suatu Abentuk dengan menggunakan media, mengekspresikan diri dengan berkarya seni menggunakan berbagai media, dan mengontrol gerakan tangan yang menggunakan otot halus (menjumput, mengelus, mencolek, mengepal, memelintir, memilin, meremas).

\section{SIMPULAN}

Berdasarkan penelitian tindakan yang dilakukan dapat dilihat bahwa kemampuan motorik halus dapat ditingkatkan melalui kegiatan melipat. Hal ini dapat dilihat dari:

1. Kemampuan motorik halus anak yang mencapai BB (Belum Berkembang) adalah ada 4 anak $(22 \%)$ pada Siklus I, dan pada Siklus II (0 \%), artinya kriteria belum berkembang berkurang $22 \%$.

2. Kemampuan motorik halus anak yang mencapai MB (Mulai Berkembang) mengalami penurunan dari 6 anak (33\%) pada Siklus I menjadi 2 anak $(11,1 \%)$ pada Siklus II, artinya penurunannya sebesar $21,9 \%$.

3. Kemampuan motorik halus anak yang mencapai BSH (Berkembang Sesuai Harapan) mengalami peningkatan yang semula 3 anak $(17 \%)$ pada Siklus I menjadi 5 anak $(27,8 \%)$ pada Siklus II, artinya peningkatannya sebesar $13,8 \%$.

4. Kemampuan motorik halus anak yang mencapai BSB (Berkembang Sangat Baik) mengalami peningkatan yang semula ada 5 anak $(28 \%)$ yang mencapai BSB pada Siklus I, menjadi 11 anak $(61,1 \%)$ pada Siklus II, artinya peningkatannya sebesar 33,1\%.

\section{UCAPAN TERIMA KASIH}

Terima kasih peneliti ucapkan kepada pihak sekolah yang sangat membantu proses dari awal hingga penyelesaian penelitian ini dan tak lupa kepada teman-teman yang saling mendukung dan memberi semangat kepada peneliti.

Copyright (C) 2020, Jurnal Pendidikan Anak ISSN 2302-6804 (print), ISSN 2579-4531 (online) 
Jurnal Pendidikan Anak, Volume 9 (2) Tahun 2020

Siti Akhiyati

\section{DAFTAR PUSTAKA}

Depdikbud. (2003). Undang-undang RI nomor 20 tahun 2003, tentang sistem pendidikan nasional.

Depdikbud. (2014). Permendikbud nomor 146, Tahun 2014, tentang kurikulum 2013 PAUD.

Dewi, N.K. (2017). Stimulasi kemampuan motorik halus anak usia 4-5 tahun melalui kegiatan seni rupa. Jurnal Pendidikan Anak Volume 7 Edisi 1.

Jakni. (2017). Penelitian tindakan kelas (PTK). Bandung: Penerbit Alfabeta.

Martinis, Y. dan Sabri, J.S. (2013). Panduan paud. Jakarta: Referesi.

Sa'dun, A. (2009). Penelitian tindakan kelas: filosofi, metodologi, implementasi: Yogyakarta: Cipta Media.

Suharsimi Arikunto. (2011). Penelitian tindakan. Yogyakarta: Aditya Madia.

Sujiono, Y.N dkk. (2010). Metode pengembangan kognitif. Universitas Terbuka. Jakarta. 